\title{
ОСНОВНІ НАПРЯМИ ДІЯЛЬНОСТІ ОПЕРАТИВНИХ ПІДРОЗДІЛІВ НАЦІОНАЛЬНОЇ ПОЛІЦІЇ УКРАЇНИ В ДОСУДОВОМУ РОЗСЛІДУВАННІ КРИМІНАЛЬНИХ ПРАВОПОРУШЕНЬ
}

Кісенко В. П.

\begin{abstract}
Стаття присвячена дослідженню основних напрямів діяльності оперативних підрозділів Національної поліції України під час досудового розслідування кримінальних правопорушень в умовах чинного Кримінального процесуального законодавства. здійснюється аналіз відповідних положень КПК України, що регламентують завдання оперативних підрозділів. Зазначено, що вони не повністю відображають увесь спектр їхньої діяльності. Звертається увага на те, що норми КПК України потребують удоскона лення з огляду на фактично виконувані оперативними підрозділами завдання під час кримінального провадження.

Ключові слова: досудове розслідування, оперативні підрозділи, кримінальне провадження, докази, доручення слідчого, слідча (розшукова) дія, розшук підозрюваного, безпека учасників кримінального судочинства.
\end{abstract}

Статья посвящена исследованию основных направле ний деятельности оперативных подразделений Национальной полиции Украины при расследовании криминальных правонарушений в условиях действующего Уголовного процессуального законодательства. Осуществляется анализ соответствующих положений УпК Украины, которые регламентируют задания оперативных подразделений. Подчеркивается, что они не полностью отображают весь спектр их деятельности. Обращается внимание на то, что нормы УПК Украины требуют усовершенствования, основываясь на фактически выполняемых оперативными подразделениями задачах в уголовном производстве.

Ключевые слова: досудебное расследование, оперативные подразделения, уголовное производство, доказательства, поручение следователя, следственное (розыскное) действие, розыск подозреваемого, безопасность участников уголовного судопроизводства.

The article is devoted to the investigation of the main directions of activity of the operational units of the National Police of Ukraine during the pre-trial investigation of criminal offenses under the conditions of the current Criminal Procedural Legislation. The relevant provisions of the CPC of Ukraine governing the tasks of the operational units are analyzed, in particular, the performance of the operational units of investigative (investigative) actions and unspoken investigative (investigative) actions on behalf of the investigator, prosecutor for the purpose of complete, comprehensive and objective investigation of the criminal offense. The peculiarities of transfer of the materials of the operative-investigative activity on the facts of criminal offenses with the purpose of commencing the pre-trial investigation, using them as evidence in criminal proceedings, including to ensure the safety of participants of criminal proceedings, are considered. Attention was paid to the involvement of operatives in the conduct of individual investigative (investigative) actions by the investigator, the prosecutor at the beginning of the pretrial investigation (when responding to statements and reports

Кісенко В. П., 2019 on criminal offenses) and at the next stage of the investigation. The leading role of operatives in the execution of investigator's decisions regarding the location of the suspected suspected persons has been determined.

It is noted that the provisions of Art. 41 of the CCP are not properly formulated and do not reflect the full range of tasks of operational units that they solve in criminal proceedings. They should fully cover all areas of activity of operational units in pre-trial investigation in view of their actual tasks. In particular, this rule requires reference to the implementation by operational units of initiative actions and measures that do not require obtaining the permission of the prosecutor or the court, in order to identify the persons involved in the commission of crimes, overcoming the counteraction to criminal proceedings and solving other problems of criminal justice.

Key words: pre-trial investigation, operative units, criminal proceedings, evidence, order of the investigator, investigative (investigative) action, search of the suspect, safety of participants of criminal proceedings.

Постановка проблеми. Із набуттям чинності Кримінального процесуального кодексу України (надалі - КПК) значно змінилися повноваження оперативних підрозділів, що змістовно визначені в параграфі 2 Глави 3 (Сторона обвинувачення) та передбачають виконання цими підрозділами певних процесуальних функцій у досудовому розслідуванні. Відповідно до ст. 5 Закону України «Про оперативно-розшукову діяльність» визначено суб'єкти ОРД, серед яких важливе місце займають підрозділи Національної поліції, а саме оперативні підрозділи кримінальної поліції та оперативні підрозділи спеціальної поліції (ОРД, ст. 5). До підрозділів кримінальної поліції належать карний розшук, Державна служба боротьби з економічною злочинністю, підрозділи боротьби з незаконним обігом наркотиків, боротьби з кіберзлочинністю, оперативної служби та оперативно-технічних заходів.

Аналіз положень ст. 41 КПК дозволяє стверджувати, що повноваження оперативних підрозділів не повністю відображають увесь спектр завдань, що вирішуються ними під час кримінального провадження. Саме кримінальна процесуальна регламентація діяльності оперативних підрозділів у сучасних умовах протидії злочинності потребує окремої уваги та ґрунтовного дослідження.

Значний внесок у наукове розроблення проблемних питань діяльності оперативних підрозділів зробили К.В. Антонов, О.М. Бандурка, А.М. Волощук, І.О. Воронов, Е.О. Дідоренко, О.Ф. Долженков, Ю.Ф. Жаріков, В.П. Захаров, А.В. Іщенко, І.П. Козаченко, Я.Ю. Кондратьєв, Д.Й. Никифорчук, Ю.Ю. Орлов, В.Л. Ортинський, Б.Г. Розовський, М.Б. Саакян, В.Є. Тарасенко та інші вчені. Однак в умовах чинного КПК України безпосередньо цим проблемам гідної уваги приділялося 
недостатньо. Складність проблеми, недостатня наукова розробленість іiі окремих аспектів не може задовольнити сучасних потреб науки та практики, реалізації принципу наступальності у протидії злочинності.

Виклад основного матеріалу. Аналіз положень чинного КПК дозволяє виділити декілька основних напрямів діяльності оперативних підрозділів у досудовому розслідуванні. Основним серед них можна вважати виконання оперативним підрозділом слідчих (розшукових) дій та негласних слідчих (розшукових) дій за дорученням слідчого. Слідчий органу досудового розслідування уповноважений доручати проведення слідчих (розшукових) дій та негласних слідчих (розшукових) дій відповідним оперативним підрозділам [3, ч. 3 ст. 40]. Потрібно зазначити, що згідно з КПК у межах кримінального провадження практично всі оперативно-розшукові заходи, що передбачені законом «Про оперативно-розшукову діяльність» і пов'язані з обмеженням конституційних прав громадян [1, ч. 2 ст. 30, ч. 2 ст. 31, ч. 2 ст. 32; 2], здійснюються у формі негласних слідчих (розшукових) дій [3, гл. 21]. Доручення на їх проведення, як правило, надсилаються начальнику оперативного підрозділу в письмовій формі і $\epsilon$ обов'язковими для виконання [3, ч. 3 ст. 41]. У дорученні повинно бути чітко сформульовано питання, що належить з'ясувати, і викладена інформація, необхідна для його виконання. Керівник оперативного підрозділу, що отримав доручення, за погодженням зі слідчим, який надав доручення, зобов'язаний у найкоротший строк організувати його виконання [3, ч. 6 ст. 232]. Під час виконання доручень слідчого працівник оперативного підрозділу користується повноваженнями слідчого [3, ч. 2 ст. 41]. При цьому працівники оперативних підрозділів можуть приймати участь у проведенні окремих слідчих (розшукових) дій, що проводить слідчий. У практичній діяльності слідчі Національної поліції найчастіше залучають працівників оперативних підрозділів під час реагування на заяви і повідомлення про кримінальні правопорушення, зокрема, до проведення таких слідчих (розшукових) дій, як огляд місцевості, приміщення, речей, документів [3, ст. 237], огляд трупа [3, ст. 238, 239] тощо. У складі слідчо-оперативної групи працівники оперативних підрозділів проводять опитування громадян, які проживають неподалік від місця події, здійснюють обстеження прилеглої території, встановлюють осіб, причетних до вчинення злочинів, а також очевидців події, потерпілих тощо [ 5, ч. 2, п. 9]. Допомога оперативних працівників може бути використана слідчим і на подальшому етапі розслідування: під час обшуку [3, ст. 234] з метою забезпечення сприятливих умов для його проведення та забезпечення безпеки учасників обшуку, під час затримання особи без ухвали слідчого судді, суду [3, ст. 207, 208] та тимчасового вилучення майна [3, ст. 167, 168], під час проведення слідчого експерименту [3, ст. 240], коли потрібна допомога у відтворенні обстановки певної події та інших випадках. Участь оперативних працівників засвідчується відповідним записом у протоколі слідчої (розшукової) дії.

У чинному КПК передбачена можливість одержання інформації про кримінальне правопорушення не лише через надходження заяв чи повідомлень, а і шляхом самостійного виявлення слідчим, прокурором або іншою службовою особою з будь-якого джерела обставин, що можуть свідчити про його вчинення [3, ст. 214]. Одним із найбільш поширених джерел, з яких слідчі, прокурори виявляють кримінальні правопорушення, $є$ матеріали ОРД, оскільки головним завданням оперативно-розшукової діяльності $є$ пошук і фіксація фактичних даних про протиправні діяння окремих осіб та груп, відповідальність за які передбачена Кримінальним кодексом України. Із цією метою оперативні підрозділи наділені відповідними правами, що дозволяють їм здійснювати як гласно, так і негласно заходи оперативно-розшукової діяльності та накопичувати оперативні матеріали, які відповідно до статті 10 Закону «Про ОРД» та ст. 99 Кримінального процесуального Кодексу України можуть бути доказами у кримінальному провадженні [2, ст.. 10; 3, ч. 2 ст. 99]. Зазначені матеріали оперативні підрозділи передають органу досудового розслідування. Згідно з вимогами відомчих Інструкцій слідчі, прокурори з дотриманням режиму таємності ознайомлюються $з$ матеріалами ОРД оцінюють їх та надають рекомендацій щодо їх достатності, а можливо, і фіксації додаткових фактичних даних про протиправні діяння окремих осіб, які засвідчують наявність в їх діях ознак злочину з метою внесення отриманих відомостей до Єдиного реєстру досудових розслідувань та початку розслідування [3, ч. 1 ст. 214]. У матеріалах ОРД також можуть бути зафіксовані факти протиправної діяльності відносно учасників кримінального судочинства, оскільки серед підстав для заведення оперативно-розшукової справи передбачено наявність достатньої інформації, одержаної в установленому законом порядку, що потребує перевірки за допомогою оперативно-розшукових заходів і засобів, про реальну загрозу життю, здоров'ю, житлу, майну працівників суду і правоохоронних органів у зв'язку з їхньою службовою діяльністю, а також особам, які беруть участь у кримінальному судочинстві, членам їх сімей та близьким родичам [2, ст. 6, 9-1; 4, ч. 2 ст. 20].

Одним із важливих завдань оперативних підрозділів у досудовому розслідуванні $\epsilon$ встановлення місця знаходження підозрюваної особи. У разі, коли підозрюваний переховується від органів слідства з метою ухилення від кримінальної відповідальності i його місцезнаходження невідоме, досудове розслідування може бути зупинено, а слідчий оголошує його розшук [3, ч. 2, ст. 280]. Про оголошення розшуку виноситься окрема постанова, а здійснення розшуку підозрюваного доручається саме оперативним підрозділам [3, ст. 281].

На підставі вищевикладеного можна дійти висновку, що діяльність оперативних підрозділів Національної поліції України в досудовому розслідуванні регламентовано чинними нормативно-правовими актами і полягає у такому:

- виконання оперативними підрозділами слідчих (розшукових) дій та негласних слідчих (розшукових) дій за дорученням слідчого, прокурора з метою повного, всебічного та об'єктивного розслідування кримінального правопорушення;

- передача органу досудового розслідування матеріалів оперативно-розшукової діяльності за фактами кримінальних правопорушень із метою початку досудового розслідування, використання їх як доказів у кримінальному провадженні, в тому числі для забезпечення безпеки учасників кримінального судочинства; 


\section{досудового слідства}

- участь оперативних працівників у проведенні окремих слідчих (розшукових) дій на початку досудового розслідування (під час реагування на заяви і повідомлення про кримінальні правопорушення) та на наступному етапі розслідування;

- виконання постанов слідчого щодо встановлення місця знаходження підозрюваних осіб, щодо яких оголошений розшук.

Висновки. Аналіз положень ст. 41 КПК дозволяє стверджувати, що вони сформульовані недостатньо коректно та не відображають увесь спектр завдань оперативних підрозділів, що вирішуються ними під час кримінального провадження. На нашу думку, положення ч. 1 ст. 41 КПК мають у повному обсязі передбачати всі напрями діяльності оперативних підрозділів у досудовому розслідуванні з огляду на фактично виконувані ними завдання. Зокрема, вказана норма потребує посилання на виконання оперативними підрозділами ініціативних дій і заходів, що не потребують одержання дозволу прокурора та/або суду, з метою встановлення осіб, які причетні до учинення злочинів, подолання протидії здійсненню кримінального провадження та вирішення інших завдань кримінального судочинства.

\section{Література}

1. Конституція України від 28 червня 1996 р. URL : http://zakon1.rada.gov.ua (дата звернення: 05.09.2019).
2. Про оперативно-розшукову діяльність : Закон України від 18 лютого 1992 р. URL : http://zakon2.rada.gov.ua (дата звернення: 05.09.2019).

3. Кримінальний процесуальний кодекс України від 13 квітня 2012 p. URL : http://zakon2.rada.gov.ua (дата звернення: 05.09.2019).

4. Про забезпечення безпеки осіб, які беруть участь у кримінальному судочинстві : закон України від 23 грудня 1993 p. URL : http://zakon1.rada.gov.ua. (дата звернення: 05.09.2019).

5. Про затвердження Інструкції з організації взаємодії органів досудового розслідування з іншими органами та підрозділами Національної поліції України в запобіганні кримінальним правопорушенням, їх виявленні та розслідуванні : наказ MBC України № 575 від 07 серпня 2017 р. URL : http://zakon2.rada.gov.ua (дата звернення: 05.09.2019).

6. Про організацію діяльності органів досудового розслідування Національної поліції України : наказ МВС України № 570 від 06 липня 2017 р. URL : http: / /zakon2.rada.gov. иа (дата звернення: 05.09.2019).

7. Тарасенко В.Є., Тарасенко Р.В. Правові засади діяльності кримінальної поліції в інтересах кримінального судочинства : монографія. Одеса, 2018. 240 с.

Кісенко В. П., ад’юнкт денної форми навчання докторантури та аспірантури Одеського державного університету внутрішніх справ 